\title{
Minyak Atsiri Daun Jeruk Purut (Citrus hystrix) dan Biaktivitasnya Terhadap Bakteri Propionibacterium acnes dan Pseudomonas aeruginosa
}

\section{Essential Oil of Kaffir Lime (Citrus hystrix) Leaves and the Bioactivity Against Bacteria of Propionibacterium acnes and Pseudomonas aeruginosa}

\author{
Diana Hala Aran ${ }^{1}$, Yeni Mariani ${ }^{2}$, Fathul Yusro ${ }^{3}$ \\ Fakultas Kehutanan Universitas Tanjungpura Pontianak \\ *Email: dianaaran00@gmail.com \\ diterima : 20 Desember 2020; dipublikasi : 31 Maret 2021 \\ DOI: $10.32528 /$ bioma.v6i1.3221
}

\begin{abstract}
ABSTRAK
Daun jeruk purut (Citrus hystrix) banyak dimanfaatkan oleh masyarakat di Kalimantan Barat sebagai bumbu masakan. Daun memiliki aroma yang khas dan berpotensi untuk diolah menjadi minyak atsiri dan digunakan sebagai antibakteri alami. Tujuan dari penelitian ini adalah menganalisis aktivitas minyak atsiri daun jeruk purut sebagai penghambat pertumbuhan bakteri Propionibacterium acnes dan Pseudomonas aeruginosa. Metode penelitian yaitu dengan destilasi uap selama 5 jam, dan pengujian aktivitas antibakteri menggunakan 4 tingkat konsentrasi minyak daun jeruk purut yaitu 0,$5 ; 1 ; 5$ dan $10 \%$. Rendemen minyak yang dihasilkan cukup tinggi yaitu 1,083\%. Minyak daun jeruk purut memiliki bioaktivitas yang rendah dalam menghambat pertumbuhan bakteri $P$. acnes dan $P$. aeruginosa dengan zona hambat yang terbentuk pada konsentrasi $10 \%$ adalah $1,8 \mathrm{~mm}$ (P. acnes) dan $1,36 \mathrm{~mm}$ (P. aeruginosa).
\end{abstract}

Kata kunci: minyak atsiri, jeruk purut, antibakteri, Propionibacterium acnes, Pseudomonas aeruginosa

\begin{abstract}
People in West Kalimantan are widely using kaffir lime leaves (Citrus hystrix) as a spice in cooking. The leaves have a distinctive aroma and have the potential to be processed into essential oils and used as a natural antibacterial. This study aims to analyze the essential oils bioactivity of kaffir lime leaves against bacteria of Propionibacterium acnes and Pseudomonas aeruginosa. The research method is by steam distillation for 5 hours, and testing for antibacterial activity using four levels of oil concentration that is $0.5 ; 1 ; 5$ and $10 \%$. The yield of oil produced was quite high, at $1.083 \%$. Kaffir lime leaf oil has low bioactivity in inhibiting the growth of bacteria $P$. acnes and $P$. aeruginosa with inhibition zones formed at a concentration of $10 \%$ are 1.8 $\mathrm{mm}(P$. acnes $)$ and $1.36 \mathrm{~mm}(P$. aeruginosa).
\end{abstract}

Keywords: essential oils, kaffir lime, antibacterial, Propionibacterium acnes, Pseudomonas aeruginosa 


\section{PENDAHULUAN}

Jeruk purut (Citrus hystrix) merupakan tanaman yang bermanfaat sebagai bahan obatan-obatan, aromaterapi, kosmetik, sampo (Budiarto et al. 2019, p. 138), dan dalam keseharian masyarakat di Kalimantan Barat digunakan sebagai bumbu masakan terutama bagian daun dan buahnya. Daun jeruk purut bernilai ekonomi tinggi dan dipasaran dijual dengan harga Rp. 14.000-16.000 perkilogram (Budiarto et al. 2019, p.141). Bagian daun memiliki aroma yang khas dan berpotensi untuk diolah menjadi minyak atsiri (Yuliani et al. 2011, p.53; Jamaluddin et al. 2017, p.61; Warsito et al. 2017, p.127). Harga minyak atsiri jeruk purut berada pada kisaran USD 65-75 perkilogram (Warsito et al. 2017, p.127). Tingginya potensi ekonomi yang dimiliki oleh tanaman jeruk purut menjadikannya sebagai tanaman yang potensial untuk dikembangkan sebagai tanaman sela pada sistem agroforestry di Kalimantan Barat. Namun, untuk sampai pada tahap pengembangan, diperlukan penelitian-penelitian pendahuluan dari berbagai aspek agar hasil yang diperoleh kedepannya dapat maksimal.

Beberapa kajian terkait minyak atsiri dari tanaman jeruk purut di Kalimantan Barat telah dilakukan seperti minyak dari kulit buah sebagai sabun aromaterapi (Hidayati 2012, p. 39) dan minyak dari daun sebagai anti rayap (Lestari et al. 2015, p.83). Minyak atsiri yang dihasilkan dari daun jeruk purut yang berasal dari luar Kalimantan Barat telah diketahui bersifat antibakteri seperti terhadap Escherichia coli, Bacillus cereus (Warsito et al. 2017, p.130), Staphylococcus aureus (Yuliani et al. 2011, p.52), dan Klebsiella pneumoniae (Jamaluddin et al. 2017, p.63). Namun hingga saat ini belum banyak data yang menunjukkan aktivitas minyak atsiri dari bagian daun jeruk purut yang berasal dari Kalimantan Barat sebagai antibakteri khususnya terhadap bakteri Propionibacterium acnes dan Pseudomonas aeruginosa.

$P$. acnes merupakan bakteri komensal yang terdapat pada kulit manusia yang dapat menyebabkan penyakit seperti endokarditis, osteomielitis, radang sendi, endophthalmitis, pansinusitis, dan sarkoidosis (Liu et al. 2015, p.1). P. aeruginosa merupakan bakteri yang telah mengalami resistensi terhadap banyak jenis antibiotik (Bassetti et al. 2018, p.2) dan menyebabkan beberapa penyakit infeksi seperti pada saluran pernapasan, saluran kemih, kulit dan jaringan lunak, dan keratitis bakteri (Streeter \& Katouli 2016, p. 25-26). Banyaknya jenis penyakit yang ditimbulkan kedua jenis bakteri tersebut dan mulai resistensinya antibiotik yang ada maka perlu dilakukan 
pencarian alternatif obat-obatan alami yang potensial kedepannya digunakan untuk penanganan kedua jenis bakteri tersebut. Tujuan dari penelitian ini adalah menganalisis aktivitas minyak atsiri daun jeruk purut sebagai penghambat pertumbuhan bakteri $P$. acnes dan $P$. aeruginosa.

\section{METODE}

Penelitian ini dilakukan selama 1 bulan dari Maret hingga April 2020 pada laboratorium Kimia Fakultas MIPA Universitas Tanjungpura dan Unit Laboratorium Kesehatan Pontianak. Peralatan yang digunakan antara lain satu set destilator uap, autoclave, cawan petri, mikropipet, dan incubator. Beberapa bahan yang dipergunakan seperti daun jeruk purut yang diperoleh dari daerah Purnama Pontianak, antibiotik amikacin, $\mathrm{MgSO}_{4}$ anhidrat, Dimethyl sulfoxide (DMSO), media MHA (Mueller Hinton Agar), bakteri P. acnes dan P. aeruginosa.

\section{Destilasi minyak atsiri}

Sebanyak $4 \mathrm{~kg}$ daun jeruk purut diambil pada sore hari, selanjutnya di cuci bersih untuk menghilangkan kotoran yang menempel dan dikeringanginkan selama \pm 1 hari. Daun yang telah siap tersebut selanjutnya dilakukan destilasi uap dengan cara memasukkan daun kedalam ketel yang telah berisi air sampai pada batas saringan, dan dilakukan pemanasan selama 5 jam. Selama proses pemanasan, uap yang mengembun pada kondensor akan keluar dan ditampung pada separator. Proses pemisahan hidrosol dan minyak dilakukan dengan memindahkan hidrosol kedalam beaker glass dan minyaknya kedalam botol vial. Botol yang berisi minyak tersebut ditambahkan $\mathrm{MgSO}_{4}$ anhidrat, kocok hingga jenuh dan biarkan terjadi proses pemisahan antara minyak dan air. Minyak yang diperoleh selanjutnya dihitung rendemennya dengan persamaan (Costa et al. 2014, p.2):

$$
\text { Rou }(\%)=\frac{M}{B m} \times 100 \%
$$

Dimana:

$$
\begin{array}{ll}
\mathrm{Rou} & =\text { rendemen minyak atsiri }(\%) \\
\mathrm{M} & =\text { massa minyak atsiri }(\mathrm{g}) \\
\mathrm{Bm} & =\text { Massa sampel }(\mathrm{g})
\end{array}
$$




\section{Aktivitas antibakteri}

Pengujian yang dilakukan menggunakan metode difusi cakram. Penelitian ini menggunakan 6 perlakuan yaitu kontrol negatif (DMSO), kontrol positif (antibiotik amikacin, $10 \mu \mathrm{g}$ ) dan empat konsentrasi minyak atsiri daun jeruk purut yaitu 0,$5 ; 1 ; 5$ dan 10\%. Tahap awal penelitian yaitu dengan menyiapkan kertas cakram berukuran 6 mm yang sebelumnya telah ditetesi $20 \mu \mathrm{L}$ minyak atsiri, DMSO untuk kontrol negatif dan antibiotik amikacin untuk kontrol positif. Kertas cakram tersebut diletakkan pada cawan petri yang sebelumnya telah diisi dengan media MHA dan isolat bakteri $P$. acnes atau $P$. aeruginosa $\left(3 \times 10^{8} \mathrm{CFU} / \mathrm{ml}\right.$ atau Mc.Farland 1$)$. Tahap berikutnya yaitu proses inkubasi pada temperatur $37^{\circ} \mathrm{C}$ dilakukan selama 24 jam (1 hari). Tahap akhir yaitu mengukur zona hambat $(\mathrm{mm})$ setelah masa inkubasi dan hasilnya dianalisis menggunakan rancangan acak lengkap (RAL) dengan alat bantu berupa software SPSS 22.

\section{HASIL DAN PEMBAHASAN Rendemen}

Hasil penelitian menunjukkan bahwa minyak atsiri yang dihasilkan berwarna kuning jernih dan memiliki aroma yang khas dengan rendemen minyak sebesar 1,083\%. Hasil ini lebih tinggi jika dikomparasikan dengan hasil penelitian Warsito et al. (2017, p.129) yang memperoleh rendemen sebesar 0,68\%, Mayasari et al. (2013, p.75) sebesar 0,88\%, dan Lestari et al. (2015, p.85) sebesar 0,92\%. Selain itu, jika dibandingkan dengan beberapa tanaman lain seperti serai wangi dengan rendemen 0,316\% (Udawaty et al. 2019, p.75), dan kayu putih sebesar 0,79\% (Utomo \& Mujiburohman, 2018, p. 127) maka rendemen minyak atsiri daun jeruk purut tergolong tinggi.

Nilai rendemen minyak atsiri dipengaruhi oleh banyak faktor seperti tempat tumbuh, umur panen, metode pemanenan bahan, metode penyulingan atau destilasi dan penanganan pasca destilasi (Wahyudi 2013, p.197). Tempat tumbuh diduga kuat berpengaruh terhadap tingginya rendemen yang dihasilkan dalam penelitian ini, hal ini karena sampel yang diambil dalam penelitian ini merupakan tanaman budidaya dipekarangan rumah yang dalam pertumbuhannya mendapatkan proses perawatan dan diberikan pupuk organik secara periodik. Cukup tingginya rendemen minyak atsiri yang dihasilkan dalam penelitian ini dapat menjadi acuan untuk penelitian kedepan bagi yang 
ingin mengarahkan pada pembudidayaannya disekitar hutan atau menjadi bagian dari tanaman sela dalam kegiatan agroforestry di Kalimantan Barat.

\section{Bioaktivitas minyak atsiri terhadap bakteri $P$. acnes dan $P$. aeruginosa}

Hasil penelitian menunjukkan bahwa minyak atsiri jeruk purut memiliki aktivitas penghambatan pertumbuhan bakteri $P$. acnes dan $P$. aeruginosa. Tingkat penghambatan yang dihasilkan tidak terlalu besar, hanya berkisar antara 0,68-1,85 mm untuk $P$. acnes dan 0,5-1,36 mm untuk $P$. aeruginosa (Gambar 1). Semakin tinggi tingkat konsentrasi yang diberikan memberikan tren peningkatan zona hambat yang terbentuk pada kedua jenis bakteri, namun peningkatan yang dihasilkan tidak terlalu besar. Secara keseluruhan, penghambatan yang dihasilkan jauh lebih rendah dibandingkan dengan kontrol positif amikacin.

Amikacin menunjukkan nilai hambatan yang besar terhadap pertumbuhan kedua jenis bakteri yang diujikan. Sebagai antibiotik golongan aminoglikosida, amikacin telah dikenal mampu mengatasi infeksi bakteri baik Gram positif maupun negatif (Krause et al. 2016, p.3). Komponen penyusun amikacin (aminoglikosida) berikatan dengan komponen anionik pada permukaan bakteri, jika pada bakteri Gram negatif yaitu pada lapisan lipopolisakarida, fospolipid dan pada Gram positif berikatan dengan protein membrane luar. Interaksi ini akan meningkatkan permeabilitas yang mengakibatkan masuknya antibiotik ini ke struktur bagian dalam dari bakteri (Ramirez dan Tomalsky 2017, p.5).

Konsentrasi terendah dari minyak daun jeruk purut yaitu $0,5 \%$ menunjukkan adanya aktivitas penghambatan walaupun tergolong sangat lemah. Jika dilihat dari analisis statistik, antara kontrol negatif dan perlakuan yang diberikan untuk kedua jenis bakteri menunjukkan perbedaan yang signifikan yang berarti minyak atsiri daun jeruk purut memiliki kemampuan sebagai penghambat pertumbuhan bakteri $P$. acnes dan $P$. aeruginosa secara nyata.

Faktor yang menyebabkan rendahnya tingkat penghambatan pertumbuhan kedua bakteri diduga karena rendahnya konsentrasi yang digunakan. Konsentrasi yang rendah berarti mengandung persentase senyawa bioaktif yang rendah dan hal tersebut berdampak pada belum mampunya untuk membunuh bakteri secara maksimal. Swamy et al. (2016, p.10) mengungkapkan bahwa terdapat hubungan positif antara kenaikan 
konsentrasi minyak atsiri dengan hambatan pertumbuhan bakteri. Pemberian konsentrasi yang rendah pada koloni bakteri umumnya dapat menghambat kerja dari enzim metabolisme bakteri, dan apabila konsentrasi minyak atsiri ditingkatkan maka akan dapat membunuh bakteri yang diakibatkan dari adanya degradasi dari dinding sel, dan membran sitoplasma (Nazzaro et al. (2013, p.1458); Man et al. (2019, p.8)).

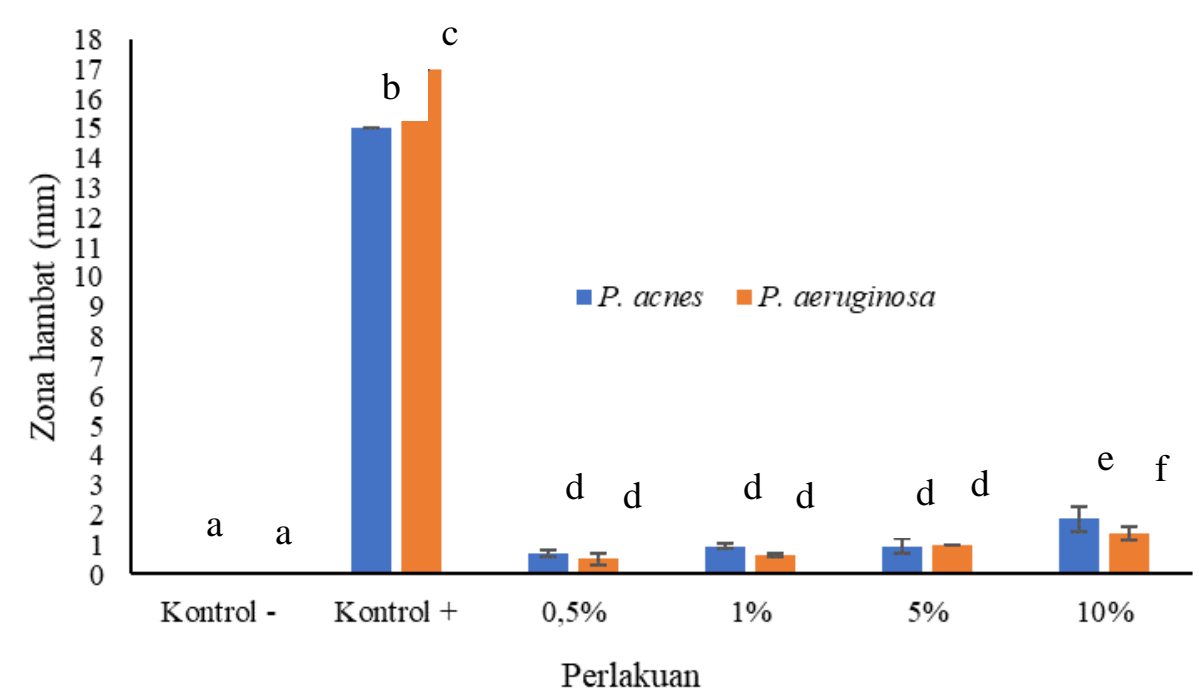

Gambar 1. Zona hambatan minyak atsiri dari daun jeruk purut (C. hystrix)

Keterangan: huruf yang sama nilai tengahnya pada perlakuan tidak memiliki perbedaan yang signifikan pada taraf kepercayaan $95 \%$

Pada penelitian terlihat bahwa minyak atsiri jeruk purut memiliki zona hambat tertinggi pada bakteri $P$. acnes yang merupakan bakteri Gram positif. Menurut Hua Li (2019, p.3) minyak atsiri yang bersifat hidrofobik akan lebih memberikan sifat antibakteri yang lebih baik pada bakteri Gram positif dibandingkan Gram negatif. Rendahnya hambatan pada $P$. aeruginosa diduga karena bakteri ini termasuk kedalam bakteri Gram oleh Orchard dan Van Vuuren (2017, p.1) serta Man et al. (2019, p.2). Komponen penyusun dari minyak atsiri yang bersifat hidrofobik akan sulit untuk merusak lapisan pelindung dari sel bakteri Gram negatif yang bersifat hidrofilik. Secara struktur, bakteri Gram negatif memiliki membran luar yang mengandung lipopolisakarida yang berperan dalam menghalangi masuknya makro molekul dan 
senyawa hidropobik ke dalam membran sel (Nazzaro et al 2013, p.1453). Bhavaniramya et al. (2019, p.51) dan Miksusanti et al. (2009, p.16) menambahkan bahwa minyak atsiri dapat bergerak ke lapisan lipid pada membran sel bakteri, menggangu struktur dari dinding sel dan menyebabkan dinding sel bakteri menjadi lebih permeabel. Perubahan permeabilitas dari dinding sel ini akan menyebabkan kebocoran pada ion dan material penyusun sel bakteri yang pada akhirnya akan menyebabkan kematian sel. Minyak atsiri dapat menjadi antibakteri karena adanya interaksi yang sinergis antar senyawa-senyawa aktif penyusunnya yang pada umumnya bersifat volatil (Rialita et al. 2019, p.5).

Minyak atsiri dari daun jeruk purut mengandung senyawa sitronelal, isopulegol, $\beta$-sitronelol, geranil asetat, sitronelil asetat, kariofilen, nerolidol dan dietil karbitol (Mayasari et al. 2013). Shrisukh et al. (2012, p.214) juga melaporkan bahwa minyak atsiri dari daun jeruk purut asal Thailand bersifat antibakteri Streptococcus, Haemophilus influenzae dan Acinetobacter baumannii, dimana bakteri tersebut merupakan bakteri yang umum menyerang saluran pernapasan. Boresiewcz et al. (2017, p.102) menambahkan bahwa minyak atsiri dari kupasan kulit buah jeruk purut juga memiliki senyawa tersebut dan mampu menghambat pertumbuhan Acinetobacter baumannii dengan konsentrasi yang diujikan lebih tinggi yaitu 12,5\%, 25\% dan 50\%.

Penghambatan bakteri $P$. acnes dan $P$. aeruginosa yang dilakukan oleh minyak atsiri daun jeruk purut menunjukkan potensi yang besar dari tanaman tersebut sebagai antibakteri alami walaupun dalam kategori yang lemah, dan penelitian-penelitian lanjutan sangat diperlukan untuk menunjang peluang dikembangkannya produksi minyak atsiri di Kalimantan Barat berbahan dasar daun jeruk purut.

\section{KESIMPULAN DAN SARAN}

Daun jeruk purut diolah menjadi minyak atsiri dengan rendemen yang cukup tinggi yaitu 1,083\%. Minyak daun jeruk purut memiliki bioaktivitas yang rendah dalam menghambat pertumbuhan bakteri $P$. acnes dan $P$. aeruginosa. Besaran zona hambat maksimum yang terbentuk pada konsentrasi $10 \%$ adalah $1,8 \mathrm{~mm}$ (P. acnes) dan 1,36 $\mathrm{mm}$ ( $P$. aeruginosa). Perlu penelitian lanjutan untuk mendapatkan tingkat penghambatan yang tinggi terhadap bakteri $P$. acnes dan $P$. aeruginosa dan perlu 
adanya pengembangan tanaman ini menjadi tanaman sela pada sistem agroforestri di Kalimantan Barat.

\section{DAFTAR PUSTAKA}

Bassetti, M., Vena, A., Croxatto, A., Righi, E., \& Guery, B. (2018). How to manage Pseudomonas aeruginosa infections. Drugs in Context, 7, 1-18. https://doi.org/10.7573/dic.212527.

Bhavaniramya S., Visnupriya S., Al-Aboody., Vijaykumar., \& Baskaran D. (2019). Role of essential oils in food safety: Antimicrobial and antioxidant applicants. Grand \& Oil Science and Technology 2 (2019): 49-55. https://dx.doi.org/10/1016/j.gaost.2019.03.001.

Borusiewicz M., Tojanowska D., Paluchowska P., Janeczko Z., Petitjean MW., \& Budak A. (2017). Cytostatic, cytotoxic, and antibacterial activities of essential oil isolated from Citrus hystrix. ScienceAsia. 43. 96-106. https://doi.org/10.2306/scienceasia 1513-1874.2017.43.096.

Budiarto, R., Poerwanto, R., Santosa, E., Efendi, D., \& Agusta, A. (2019). Production, Post-Harvest and Marketing of Kaffir Lime (Citrus hystrix DC) In Tulungagung, Indonesia. Journal of Tropical Crop Science, 6(02), 138-143. https://doi.org/10.29244/jtcs.6.02.138-143

Costa, O. B. da, Del Menezzi, C. H. S., Benedito, L. E. C., Resck, I. S., Vieira, R. F., \& Ribeiro Bizzo, H. (2014). Essential Oil Constituents and Yields from Leaves of Blepharocalyx salicifolius (Kunt) O. Berg and Myracrodruon urundeuva (Allemão) Collected during Daytime . International Journal of Forestry Research, 2014, 1-6. https://doi.org/10.1155/2014/982576

Hidayati. (2012). Distilasi Minyak Atsiri dari Kulit Jeruk Purut dan Pemanfaatannya dalam Pembuatan Sabun Aromaterapi. Biopropal Industri, 3(2), 39-49. https://doi.org/10.36974/jbi.v3i2.737.

Hua Li., Z., Cai Ming., Shuai Liu Y., Long Sun P., \& Lei Luo S. (2019). Antibacterial Activity and Mechanism of Essential Oil From Citrus medica L. var. sarcodacytylis. Molecules. 24. 1-10. https://doi.org/10.3390/molecules24081577.

Jamaluddin, N., Pulungan, M. H., \& Warsito. (2017). Uji Aktivitas Antibakteri Minyak Atsiri Jeruk Purut (Citrus hystrix DC) terhadap Klebsiella pneumoniae ATCC. Industria: Jurnal Teknologi Dan Manajemen Agroindustri, 6(2), 61-66.

Krause KM., Serio AW, Kane TR., \& Connolly LE. (2016). Aminoglycosides: An Overview. Cold Spring Harb Perpsect Med. 6 (6): 1-18. http://doi.org.10.1101/cshperspect.a027029.

Lestari, S., Jayuska, A., \& Indrayani, Y. (2015). Bioaktivitas Minyak Atsiri Daun Jeruk 
Purut (Citrus hystrix) Terhadap Rayap Tanah (Coptotermes sp.). Jurnal Kimia Khatulistiwa, 4(4), 83-88.

Liu, P.-F., Hsieh, Y.-D., Lin, Y.-C., Two, A., Shu, C.-W., \& Huang, C.-M. (2015). Propionibacterium acnes in the Pathogenesis and Immunotherapy of Acne Vulgaris. Current Drug Metabolism, 16(4), 245-254. https://doi.org/10.2174/1389200216666150812124801.

Man, A., Santacroce L., Jacob R., Mare A., \& Man L. (2019). Antimicrobial Activity of Six Essential Oils Against a Group of Human Pathogens: A Comparative Study. Pathogens. 8 (15): 1-11. https://doi.org/ 10.3390/pathogens8010015.

Mayasari, D., Jayuska, A., \& Wibowo, M. A. (2013). Pengaruh Variasi Waktu dan Ukuran Sampel terhadap Komponen Minyak Atsiri dari Daun Jeruk Purut (Citrus hystrix DC.). Jurnal Kimia Khatulistiwa, 2(2), 74-77.

Misusanti, Laksi BS., Syarif R., Pontjo B., \& Mulyadi GT. (2009). Antibakterial activity of temu kunci (Kaempheria pandurata) essential oil against Bacillus cereus. Med. J. Indones. 18 (1). 10-17. https://doi.org/10.13181/mji.v18i1.331.

Nazzaro F., Fratianni F., De Martino L., Coppola R., \& De Feo V. (2013). Effect of Essential Oils on Pathogenic Bacteria. Pharmaceuticals. 6 (12): 1451-1474. https://doi.org/ 10.3390/ph6121451.

Orchard A., \& Van Vuuren S. (2017). Commercial Essential Oils as Potential Antimicrobial to Treat Skin Diseases. Evidence-Based Complementary and Alternative Medicine. 4517971: 1-92. https://doi:10.1155/2017/4517971.

Rialita T., Radiani H.,\& Alfiah D. (2019). Antimicrobial Activity of The Combination of Red Galangal (Alpinia purpurata K. Schum) and Cinnamon (Cinnamomum burmanii) Essential Oils on Escherichia coli and Staphylococcus aureus bacteria. IOP Conf. Series: Journal of Physics: Conf. Series. 1217: 1-10. https://doi:10.1088/1742-6596/1217/1/012132.

Ramirez MS., \& Tomalsky ME. (2017). Amikacin: Uses, resistance, and prospects for inhibition. Molecules. 22. 1-23: https://doi:10.3390/molecules22122267.

Shrisukh, V., Tribuddharat C., Nukoolkarn V., Bunyapraphatsara, N., Chokephaibulkit K., Phoomniyom S., Chuanphung S., \& Srifuengfung S. (2012). Antibacterial Activity of Essential Oils from Citrus hystrix (Makrut Lime) Against Respiratory $\begin{array}{llll}\text { Tract } & \text { Pathogens. } & \text { 212-217. }\end{array}$ https://doi:10.2306/scienceasia1513-1874.2012.38.212.

Streeter, K., \& Katouli, M. (2016). Pseudomonas aeruginosa: A review of their Pathogenesis and Prevalence in Clinical Settings and the Environment. Infection, Epidemiology and Medicine, 25-32. https://doi.org/10.18869/modares.iem.2.1.25. 
Swamy MK., Aktar MS., dan Sinniah UR. (2016). Antimicrobial Properties of Plant Essential Oils Against Human Pathogens and Their Mode of Action: An Updated Review. Evidende-Based Complementary and Alternative Medicine. 12 (20). 121. https://doi.org/10.1155/2016/3012462.

Udawaty, W., Yusro, F., \& Sisillia, L. (2019). Identifikasi Senyawa Kimia Minyak Sereh Wangi Klon G3 (Cymbopogon nardus L.) dengan Media Tanam tanah Gambut dan Potensinya Sebagai Antibakteri Enterococcus faecalis. Jurnal Tengkawang, 9(2), 71-81. http://dx.doi.org/10.26418/jt.v9i2.

Utomo, D. B. G., \& Mujiburohman, M. (2018). Pengaruh Kondisi Daun dan Waktu Penyulingan terhadap Rendemen Minyak Kayu Putih. Jurnal Teknologi Bahan Alam, 2(2), 124-128.

Wahyudi. (2013). Buku Pegangan Hasil Hutan Bukan Kayu (W. Syafii, ed.). Pohon Cahaya Tirtodipuran, Yogyakarta.

Warsito, Hidayat, N., \& Yasri Putri, A. (2017). Uji Aktivitas Minyak Jeruk Purut dari Daun, Ranting, dan Kulit Buah terhadap Bakteri Escherichia coli dan Bacillus cereus. Jurnal Kimia Dan Pendidikan Kimia, 2(3), 126-132. https://doi.org/10.20961/jkpk.v2i3.11856

Warsito, Noorhamdani, Sukardi, \& Suratmo. (2017). Aktivitas Antioksidan dan Antimikroba Minyak Jeruk Purut (Citrus hystrix DC.) dan Komponen Utamanya. Journal of Enviromental Engineering and Sustainable Technology, 4(1), 13-18. https://doi.org/10.21776/ub.jeest.2017.004.01.3

Yuliani, R., Indrayudha, P., Septi, D., \& Rahmi, S. (2011). Aktivitas Antibakteri Minyak Atsiri Daun Jeruk Purut (Citrus hystrix) terhadap Staphylococcus aureus dan Escherichia coli. Pharmacon, 12(2), 50-54. 